\title{
The age of the Kap Washington Group volcanics, North Greenland
}

\author{
OLE LARSEN
}

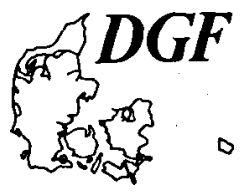

\author{
Larsen, O.: The age of the Kap Washington Group volcanics, North Greenland. Bull. geol. Soc. \\ Denmark, vol. 31, pp. 49-55, Copenhagen, November 15th, 1982. \\ https://doi.org/10.37570/bgsd-1982-31-04
}

\begin{abstract}
The Kap Washington Group of peralkaline volcanics is exposed along the coast of North Greenland at $40^{\circ} \mathrm{W}$. This coastal region is intruded by numerous NNE-NW-trending dolerite dykes of alkaline affinity. The volcanics and their basic intrusive counterparts appear to be related to the initial rifting in the Arctic Ocean basin. The timing of this rifting may be supported by accurate dating of the associated volcanic activity. An improved $\mathrm{Rb} / \mathrm{Sr}$ age of $64 \pm 3$ million years (i.e. approximately at the Cretaceous-Tertiary boundary) has been determined on rhyolitic lavas collected at Kap Kane, probably near the top of the volcanic sequence. The extrusive volcanic activity probably started already in late Cretaceous time, as in-dicated by fossil plant remains, found in sediments interbedded with the lavas on Lockwood Ø.
\end{abstract}

O. Larsen, Geological Central Institute, Øster Voldgade 10, 1350, København K, Denmark, June 28th, 1982.

\section{Introduction}

The Kap Washington Group volcanics, first noted by Koch (1923, p. 193), are exposed on the coast of North Greenland at Kap Cannon, Kap Washington, Kap Kane and on the northern part of Lockwood $\varnothing$ (figs. 1\&2). Kap Washington and Kap Cannon were briefly examined by members of the British Joint Services Expedition to North Greenland in 1969 (Dawes \& Soper, 1970; Dawes, 1971). The volcanics comprise a sequence of southward-dipping flows of basaltic to rhyolitic lavas and include pyroclastics ranging from breccias to tuffs. The volcanics are cut off to the south by a southerly dipping thrust plane named the Kap Cannon Thrust. This thrust separates the volcanics of the Kap Washington Group from low-grade metamorphic psammites belonging to the North Greenland fold belt (Dawes, 1976), where orogenic activity took place in late Devonian to early Carboniferous time (Surlyk, Hurst \& Bjerreskov, 1980; Springer, 1981). Although some of the lavas close to the Kap Cannon Thrust are crushed and partly recrystallised, large parts of the Kap Washington volcanics display very little alteration of their primary textures. Accordingly the Kap Washington volcanics were regarded as a suite of young extrusives post-dating the Palaeozoic deformation in the fold belt ( $\mathrm{Da}-$ wes \& Soper. 1973). K/Ar ages of 35 and 32 million years were obtained on lavas from Kap Washington (Dawes \& Soper, 1970), but these young dates could reflect a tectonic overprint caused by movements along the Kap Cannon Thrust, and the volcanics might well be older than these $\mathrm{K} / \mathrm{Ar}$ ages seem to indicate.

In the mid-1970'ies it was, in fact, suggested that the extrusives formed in the Palaeozoic and are related to the orogenesis in the fold belt. In order to settle the argument about the age of the Kap Washington volcanics five of the least altered samples from Kap Washington were selected for $\mathrm{Rb} / \mathrm{Sr}$ whole rock dating. The samples did not yield a perfect isochron, but a preliminary age of 63 million years was suggested by Larsen, Dawes \& Soper (1978). The volcanic activity could now be placed in time near the Cretaceous-Tertiary boundary.

The regional mapping of the North Greenland fold belt during the summer months of 1979 and 1980 has contributed considerably to understanding the tectonic setting in which the Kap Washington volcanics were formed. Detailed mapping and sampling proved that basalt and feldsparphyric trachytes are associated with the earlier reported rhyolites. Riebeckitic amphibole was detected in the groundmass of both trachytes and rhyolites. Brown \& Parsons (1981) conclude that the volcanic rocks are of peralkaline type. Interpretation of chemical analyses of main ele- 


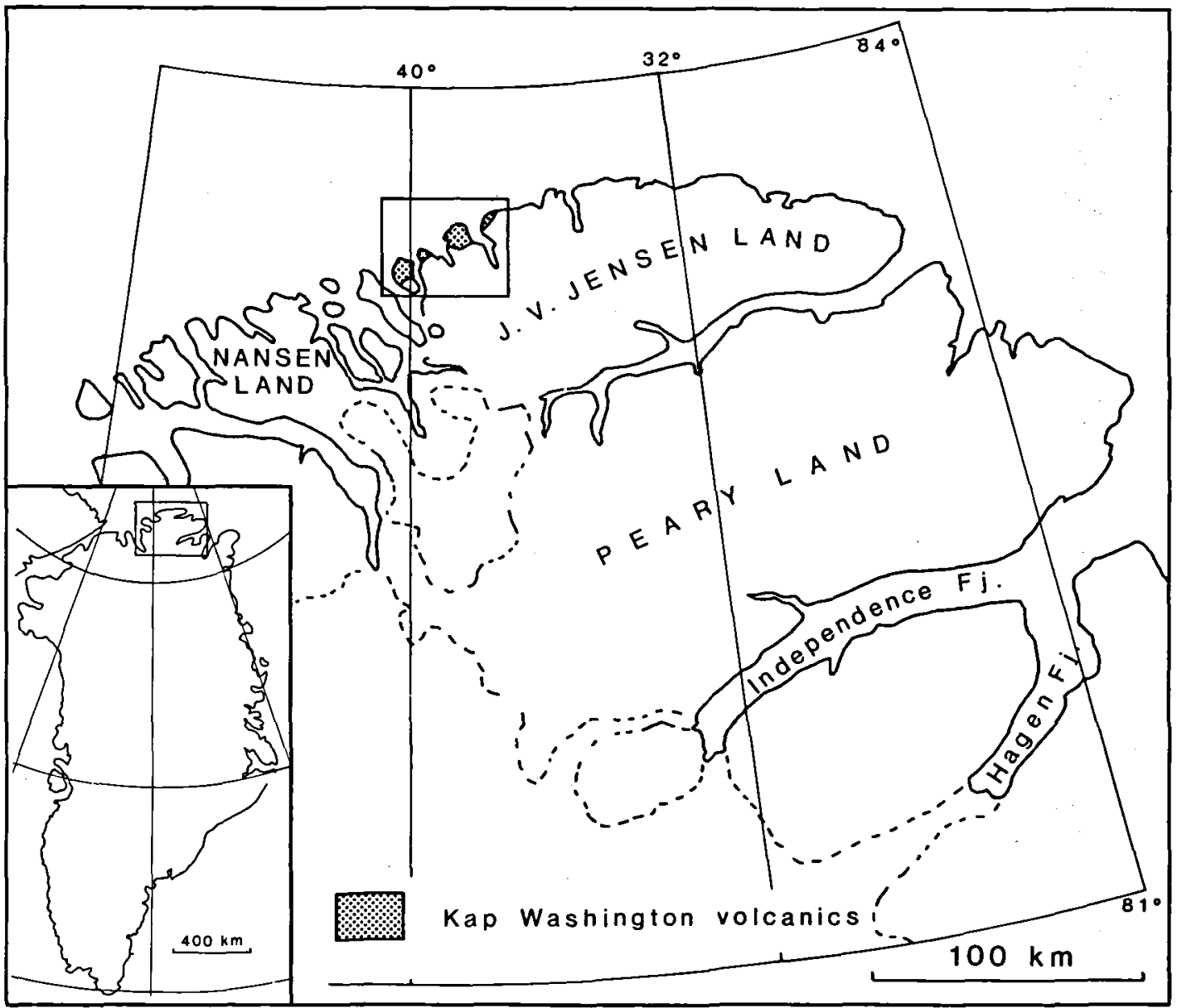

Fig. 1. Map of eastern North Greenland showing the location of the Kap Washington area.

ments as well as trace elements (Batten et al., 1981; Soper, Dawes \& Higgins, 1982) all support this conclusion. The Kap Washington Group apparently extruded in an area of crustal tension and deep rifting. This immediately implies that this volcanism must be related in some way to the tectonic movements which in late Cretaceous and Tertiary time led to the formation of the present Arctic Ocean.

Soper et al. (1982) suggest that swarms of NNE-NW trending dykes cutting the Palaeozoic structures of the North Greenland fold belt (Koch, 1920) may be related to the peralkaline volcanism. These dykes are dolerites of alkaline affinity, and they range in thickness from $25 \mathrm{me}-$ ters to 200 meters. They comprise up to 20 percent of the Palaeozoic terrain adjoining the coastal volcanic area. On Lockwood $\varnothing$ similar dolerites are seen to cut late Carboniferous to Permian cherty limestones and shales, sediments referable to the Wandel Sea Basin (Håkansson, Heinberg \& Stemmerik, 1981). On Lockwood Ø the dolerites furthermore seem to intrude black shales containing plant remains of mid- to lateCretaceous age (Batten et al., 1981).

The dolerite swarm may be feeder dykes to a basal series of basaltic lavas. Such lavas have only been recorded on Lockwood $\varnothing$ (Brown \& Parsons, 1981), but the areal extent of the dyke swarm suggests, that the mafic volcanics once covered a large area in North Greenland. Regional uplift and subsequent erosion of the fold belt in Cenozoic time (Soper et al., 1982) has apparently removed most of these lavas leaving only small parts of the lava sequence in thrust- and faultbounded blocks along the coast. The general 
north-south trend of the dolerite dyke swarm indicates that the tensional forces acting on the region have had an east-westerly direction. This corresponds to the direction of plate motion in the floor of the Arctic Ocean.

Recent aeromagnetic surveys (Vogt, Taylor, Kovacs \& Johnson, 1979; Taylor, Kovacs, Vogt \& Johnson, 1981) have strengthened the evidence for two parallel lines of sea floor spreading in the Arctic Ocean: an extinct spreading centre through the middle of the Makarov Basin and the presently active Nansen-Gakkel Ridge in the Eurasia Basin (see also review by Sweeney, Irving and Geuer, 1978).

Predrift plate positions are still very tentative, but most reconstructions place the spreading centre of the Makarov Basin as well as the initial Nansen-Gakkel Ridge off the north coast of Greenland. Sea floor spreading took place in the
Makarov Basin from late-Cretaceous (anomaly 34) time to Eocene (anomaly 19) time. Subsequent spreading in the Eurasia Basin has moved the Makarov Basin spreading center to the west, while the Nansen-Gakkel Ridge shifted position eastwards in relation to North Greenland. The linear magnetic anomalies in the Eurasia Basin can only date the onset of spreading from the Nansen-Gakkel Ridge as pre-anomaly 24 , which according to the time scale of Hailwood et al. (1979) corresponds to an age of $52 \mathrm{Ma}$., early Eocene. As the timing of the spreading events in the Polar Sea receive increasing interest the age of the volcanic activity in the Kap Washington area becomes more important. This paper reports the result of $\mathrm{Rb} / \mathrm{Sr}$ isotopic work on a new suite of samples from the Kap Washington Group volcanics.

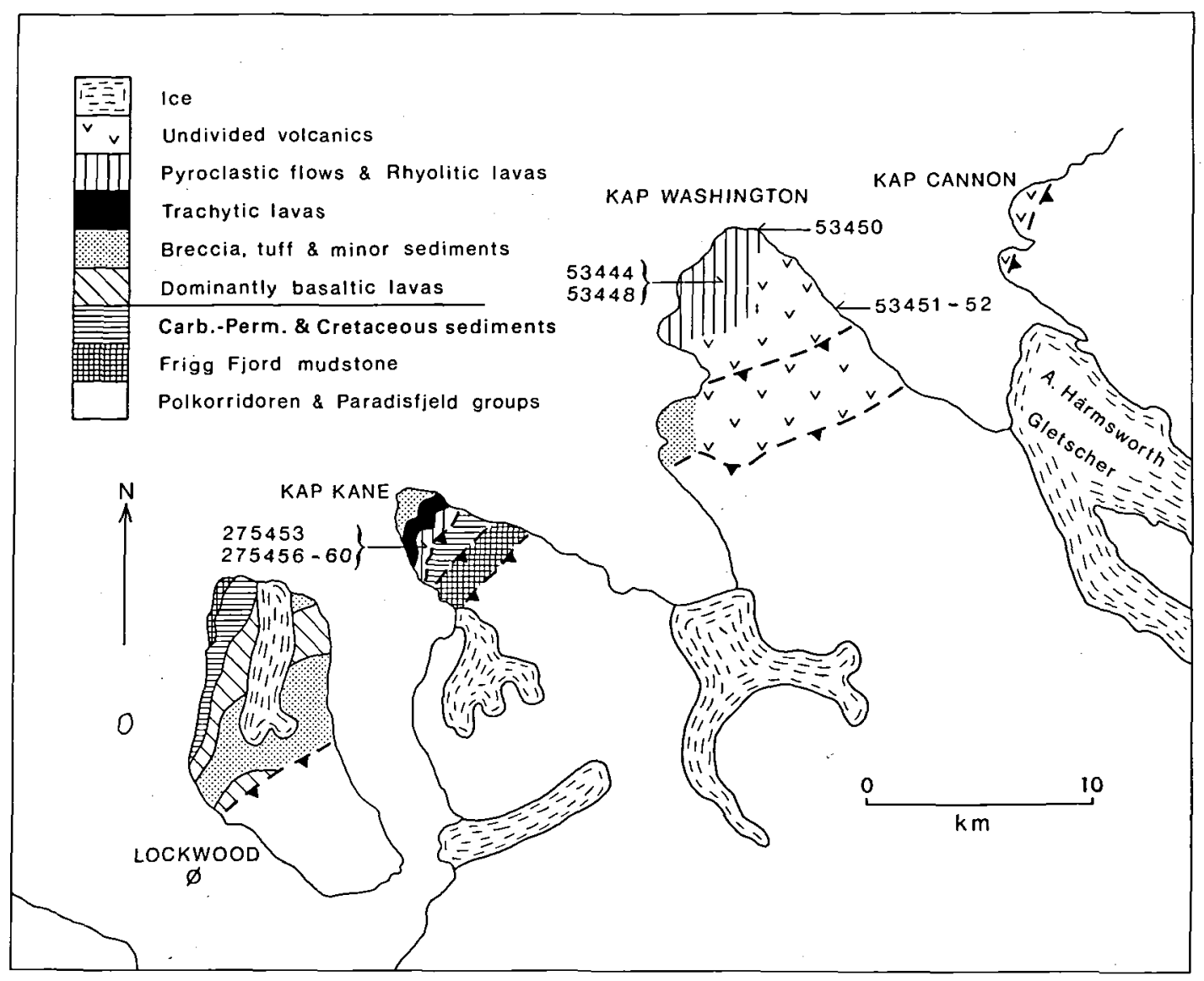

Fig. 2. Map of the Kap Washington area (from Brown \& Parsons, 1981). 


\section{The Samples}

\section{Kap Washington}

The samples used in the preliminary dating reported by Larsen et al. (1978) were all from the Kap Washington area. They were collected during the 1969 expedition at three different localities. According to chemical analyses (Larsen, Dawes \& Soper, 1978) these samples are all of rhyolitic composition. However, two samples collected on the mountain above Kap Washington (53444 and 53448) are aphyric to microphyric in contrast to the remaining three samples from the coastal localities, which carry abundant quartz and anorthoclase feldspar phenocrysts in their flow-banded matrix of devitrified glass. These differences are reflected also in the chemistry, where the former lavas are dominantly sodic, while the porphyritic rocks display approximately equal proportions of $\mathrm{Na}$ and $\mathrm{K}$.

Sample $5344438^{\circ} 36^{\prime} \mathrm{W} / 83^{\circ} 32^{\prime} \mathrm{N}$ Mountain above Kap Washington, alt. $880 \mathrm{~m}$. Microphyric dark grey soda rhyolite. Anhedral phenocrysts of quartz and anorthoclase and less than 1 millimeter in size are embedded in a microcrystalline matrix. Thin streaks of chlorite appear to be remnants of crushed and sheared mafic mineral components.

Sample 53448 Locality as above.

Light brownish-grey aphyric soda rhyolite containing rounded clasts of devitrified glassy lava. The host rock is composed of quartz and alkali feldspar grains, less than 0.02 millimeter in size, in a vitric matrix.

Sample $5345038^{\circ} 29^{\prime} \mathrm{W} / 83^{\circ} 33^{\prime} \mathrm{N}$ Northeast cape of Kap Washington, sea level. Field description: Ignimbrite. Black peralkaline rhyolite with euhedral anorthoclase phenocrysts in a flow-banded matrix. Dense bands of microcrystalline matrix with abundant microlites of pyroxene and an opaque mineral are separated by clear bands of devitrified glass.

Sample $5345138^{\circ} 12^{\prime} \mathrm{W} / 83^{\circ} 31^{\prime} \mathrm{N}$ Immediately north of glacier entering Benedict Fjord east of Kap Washington, sea level. Grey, probably ignimbritic, alkaline rhyolite with abundant phenocrysts of anhedral to subhedral anorthoclase up to millimeter size. The more dense part of the microcrystalline matrix is full of bluish green microlites, assumed to be alkali amphibole, and euhedral grains of magnetite.

Sample 53452 Locality as above.

Grey, probably ignimbritic, flow of rhyolite with abundant subhedral phenocrysts af quartz and anorthoclase. Polycrystalline felsic aggregates may be recognized as remnants of crushed and smeared phenocrysts. Such felsic aggregates are in strong contrast to the dense microcrystalline matrix speckled with grains of an opaque mineral.

\section{Kap Kane. $39^{\circ} 40^{\prime} \mathrm{W} / 83^{\circ} 26^{\prime} \mathrm{N}$}

Brown and Parsons (1981) devide the volcanic sequence at Kap Kane into the following units:
Top: Thin, aphyric basaltic lavas.

Rhyolitic flow-banded lava.

Feldsparphyric trachytes interbedded with conglomerates and red sandstones.

Bottom: Breccias and tuff-breccias.

Five of the analysed samples were collected from the 50 meter thick section of "rhyolitic flowbanded lava" near the top of the 1500 meter thick lava succession at Kap Kane. These samples all carry sodic feldspar with albite twinning as their main porphyric mineral. Larger grains of quartz are limited to certain flow-units or singular flow-bands. It appears that the samples from this part of the Kap Kane section are more sodic than the rocks dated from Kap Washington. However, no chemical analyses are available at the present time. Sample 275453 represents the "feldsparphyric trachytes" exposed below the flow-banded lavas. Here euhedral anorthoclase occurs as the only phenocryst mineral.

Sample 275453 Alt. $400 \mathrm{~m}$. Brownish grey porphyritic lava separated from overlying main rhyolitic series by approximately 50 meters of pyroclastics (breccias and tuffs). The phenocrysts are prismatic euhedral anorthoclase crystals up to 5 millimeters in size. All major grains display intense penetrative twinning. Quartz was not identified among the porphyritic grains, but quartz joins skeletal laths of twinned alkali feldspar in the matrix, where the grain size is below 0.1 millimeter. The now devitrified matrix must have had a considerable glassy component. Patches of hematite have formed interstitially and is responsible for the brown colouration of the rock.

Sample 275456 Alt. $475 \mathrm{~m}$. Black, porphyritic lava of glassy appearance from the lower part of the main thyolitic series, which forms the top 50 meters of Kap Kane. In thin section euhedral phenocrysts up to 2 millimeters in size may be identified as albite-twinned plagioclase, often clouded by secondary alteration prodücts. Potash feldspar phenocrysts occur as clear anhedral grains and as rounded aggregates of $\mathrm{K}$-feldspar grains. A few long prisms of green aegirine? (in part altered to chlorite) and scattered euhedral crystals of ore also belong to the phenocryst phase. The glassy matrix crystallised radially from points on the surface of feldspar phenocrysts. As a result of this devitrification crystallites of hematite were exsolved from the matrix. Angular patches devitrified with the formation of a microspherulitic texture.

Sample 275457 Alt. 485 m. Brown, faintly flow-banded lava with subrounded phenocrysts of variable appearance up to 3 millimeters in size. Viewed in hand specimen only, white grains of plagioclase? feldspar and clear grains of $\mathrm{K}$-feldspar? seem to be the main phenocrystic grains. Anhedral grains of quartz up to millimeter size are limited to certain bands. The flow banding in the matrix is marked by reddish-brown streaks extending from the surroundings of phenocrystic grains. These streaks appear to have formed by partial devitrification of the glassy matrix.

Sample 275458 Alt. $510 \mathrm{~m}$. Light grey, strongly flow-banded unit. As viewed only in hand specimen the microcrystalline matrix contains subhedral grains of feldspar (plagioclase?) and 
rounded grains, which may be intergrowths of quartz and K-feldspar.

Sample 275459 Alt. $520 \mathrm{~m}$. Rhyolitic lava, very light grey in colour, with a strong irregulàr flow-banding along which the rock will easily fracture. Millimeter-size rounded aggregates of plagioclase and single euhedral plagioclase crystals (0.3-1 millimeters) are embedded in a felsitic matrix where quartz grains of variable size and aggregates with $\mathrm{K}$-feldspar demonstrate that the matrix was only in part vitric at the time when the lava flow cooled.

Sample 275460 Alt. $520 \mathrm{~m}$. Brownish grey rhyolite with spherulitic nodules up to 5 centimeters in size. Where spherulites are not developed the rock is clearly flow-banded with euhedral feldpars (plagioclase?) set in a uniformly microcrystalline, flow-banded matrix.

\section{Methods}

$\mathrm{Rb} / \mathrm{Sr}$ ratios were determined by $\mathrm{X}$-ray fluorescence analysis using a semi-manually operated Philips PW1410 spectrometer. The standard $\mathrm{GSP}-1(\mathrm{Rb} / \mathrm{Sr}=1.093)$ was used as reference standard. Errors in $\mathrm{X}$-ray determination of $\mathrm{Rb} / \mathrm{Sr}$ ratios are estimated to be around \pm 1 percent for most samples, while figures given for elemental concentrations are only rough estimates (better than \pm 20 percent). Two of the Kap Washington lavas have very low strontium contents and these samples have therefore been assigned an error of \pm 3 percent on their $\mathrm{Rb} / \mathrm{Sr}$ ratios. The isotopic composition of strontium was measured on unspiked samples using a Varian MAT TH5 solid source mass spectrometer with digitized data output. The chemical separations and massspectrometric measurements were run together

Table 1

\begin{tabular}{lcccc}
\hline $\begin{array}{l}\text { Sample } \\
\text { GGU no. }\end{array}$ & & & $\mathrm{Rb}$ & $\mathrm{Sr}$ \\
& ${ }^{87} \mathrm{Rb} /{ }^{86} \mathrm{Sr}$ & ${ }^{87} \mathrm{Sr} /{ }^{86} \mathrm{Sr}$ & $\mathrm{ppm}$ & $\mathrm{ppm}$ \\
\hline Kap Washington: & & & & \\
$53448(-)$ & 1.08 & 0.7096 & 20 & 53 \\
$53444(-)$ & 11.4 & 0.7199 & 111 & 28 \\
53452 & 17.8 & 0.7219 & 117 & 19 \\
53451 & 91.1 & 0.7922 & 151 & 5 \\
53450 & 102.2 & 0.7982 & 203 & 6 \\
& & & & \\
Kap Kane: & & & & \\
275456 & 1.77 & 0.7090 & 138 & 225 \\
275453 & 5.79 & 0.7118 & 117 & 58 \\
275457 & 5.86 & 0.7120 & 216 & 107 \\
275458 & 10.0 & 0.7169 & 250 & 71 \\
275460 & 11.8 & 0.7177 & 259 & 63 \\
275459 & 12.6 & 0.7182 & 246 & 56 \\
\hline
\end{tabular}

Samples marked $(-)$ were not included in the regression. with rocks of highly variable isotopic compositions which is reflected in poor reproducibility in the isotopic measurements. A mean standard deviation of \pm 0.0007 was estimated from 6 duplicate measurements on Kap Kane lavas. The isotopic measurements on Kap Washington lavas may have been slightly better, but no duplicates are available for estimating the reproducibility. The isochron slope and average initial ratio were calculated using the regression treatment suggested by McIntyre, Brooks, Compston \& Turek (1966). A decay constant of $1.42 \times 10^{-11} \mathrm{y}^{-1}$ was used in calculating the age.

\section{Results}

The best-fit line based on the six Kap Kane samples has a slope corresponding to an age of 63.7 million years $(M S W D=0.60)$. The age error is estimated to be \pm 5 million years $(1 \sigma)$. If the three Kap Washington samples with highest $\mathrm{Rb} / \mathrm{Sr}$ ratios are included in the regression the same age is obtained (MSWD $=0.89$ ), but the $1 \sigma$ error is reduced to \pm 1.5 million years. In this regression we have allowed for errors of \pm 3 percent on the two Kap Washington samples with very low Sr-contents (samples 53450 and 53451). The initial isotopic ratio based on all 9 samples is $0.7070 \pm 0.0004$.

The low MSWD-value gives us no possibility of detecting scatter beyond the limits of analytical error. Nevertheless, we could well imagine that the lavas originally displayed a variation in their Sr-isotopic composition. For this reason the two Kap Washington samples (53444 and 53448) were not included in the regression. These two samples are believed to represent lavas with initial isotopic ratios significantly above average (approximately 0.709).

We conclude that the age of the Kap Kane and Kap Washington rhyolitic lavas is $64 \pm 3$ million

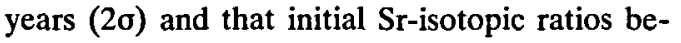
tween 0.707 and 0.709 have been detected.

\section{The age of the Kap Washington Group volcanics}

The improved $\mathrm{Rb} / \mathrm{Sr}$ age determination reported in this paper confirms the preliminary age by 


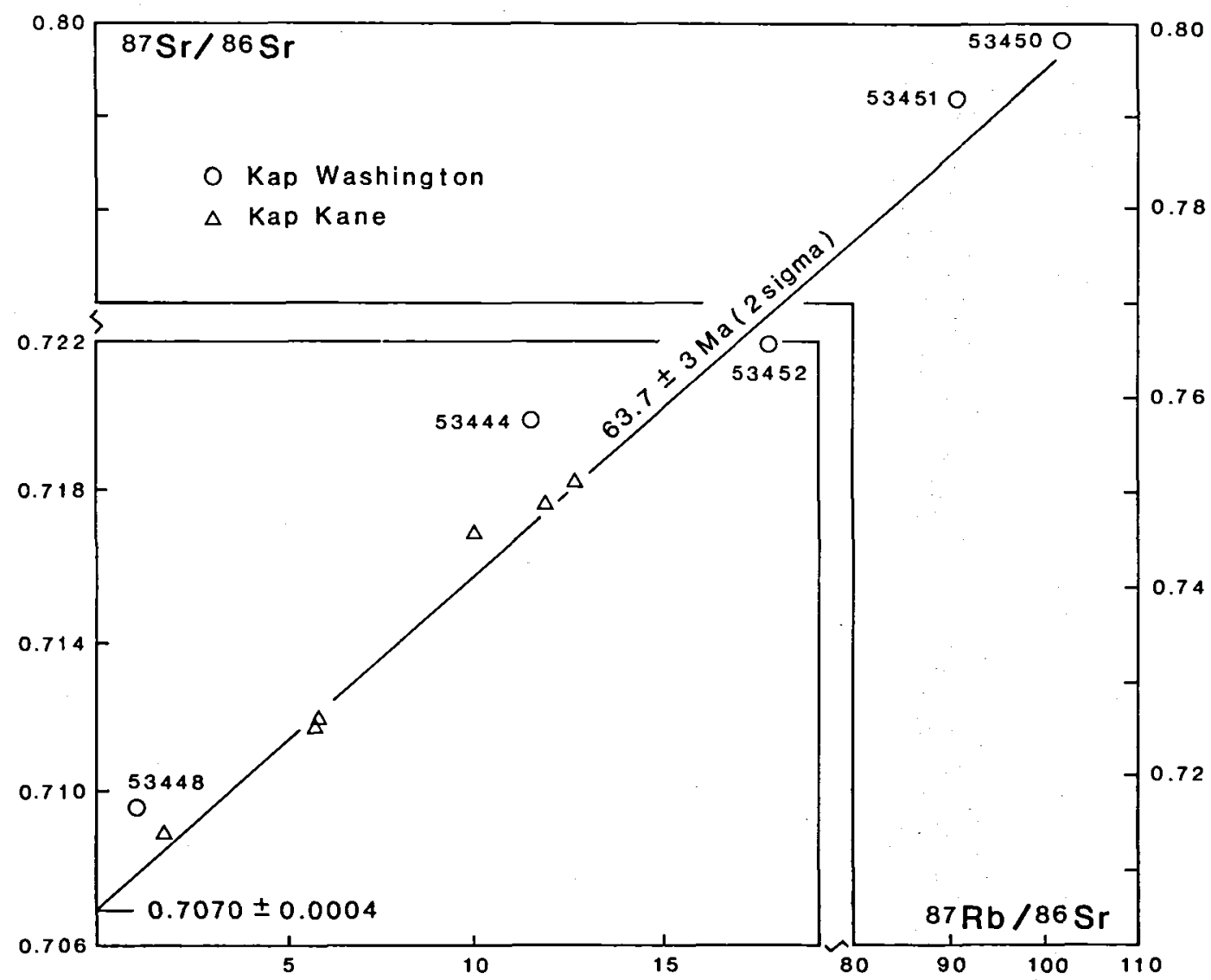

Fig. 3. BPI-plot of $\mathrm{Rb} / \mathrm{Sr}$-isotopic data. The isochron is based on 6 samples from Kap Kane and 3 samples from Kap Washington. Other data are plotted for reference.

Larsen et al. (1978). The rhyolitic lavas used for this dating work apparently extruded approximately at the Cretaceous-Tertiary boundary. If this age determination is to be applied to problems of sea floor spreading, it must be remembered that the rhyolitic lavas dated represent only the very top of a volcanic sequence of several kilometers thickness (Brown and Parsons, 1981). As mentioned earlier, $1.5 \mathrm{~km}$ of volcanic flows, breccias and tuffs were recorded at Kap Kane, and 2-3 times this amount are exposed on Lockwood $\varnothing$. The volcanic activity might have take place over a considerable period of time.

Batten et al. (1981) report the occurrence of spores and angiosperm pollen grains (Aquilapollenites, Mancicorpus and Triprojectus) in black shales interbedded with the pyroclastics on Lockwood $\varnothing$ about $3 \mathrm{~km}$ above the base of the volcanics. These microfossils are interpreted to be of late Cretaceous age, Campanian or Maas- trichtian. At the base of the volcanics other black shales and sandstones are found, and these contain fragments of angiosperm leaves. A tentative interpretation of the available material will not allow the extrusive volcanic activity to have started earlier than Cenomanian time.

Soper et al. (1982) suggest, that the volcanic activity in North Greenland is related to an early tectonic phase in the history of the Eurasia basin. The age evidence as presented in this paper appears to favor the interpretation, that rifting in the Kap Washington area is related to the opening of the Makarov basin, where spreading apparently started in the late Cretaceous.

Acknowledgements. The author wishes to thank the Geological Survey of Greenland for supporting the field work in Greenland and for permission to publish this report. The project was further supported by the Danish Natural Science Research Council and by the University of Copenhagen. 


\section{Dansk sammendrag}

Kap Washington vulkaniterne er blottet langs Grønlands nordkyst ved $40^{\circ}$ vestlig længde $i$ et område, der gennemskæres af talrige doleritgange med en dominerende strygningsretning mellem NNØ og NV. Vulkaniterne omfatter basalter, trachyter og peralkaline rhyoliter. De synes ligesom gangintrusionerne at være knyttet til den begyndende riftdannelse i Polbassinet omkring grænsen Kridt-Tertiær. Dateringen af denne riftdannelse kan understøttes af en nøjagtig aldersbestemmelse af den tilhorende vulkanske aktivitet. $\mathrm{Rb} / \mathrm{Sr}$ datering af rhyolitiske lavaer indsamlet på Kap Kane i et niveau, der formodes at ligge nær toppen af den vulkanske lagserie, har givet en alder på $64 \pm 3$ millioner år (dvs. omkring gransen Kridt-Tertiær). Plantefossiler fundet $\mathrm{i}$ sedimenter, der på Lockwood $\varnothing$ er indlejret i lavaserien, tyder på, at vulkanismen i området er begyndt allerede i Øvre Kridt.

\section{References}

Batten, D. J., Brown, P. E., Dawes, P. R., Higgins, A. K., Eske Koch, B., Parsons, I \& Soper, N. J. 1981: Peralkaline volcanicity on the Eurasia Basin margin. Nature 294 (5837), 150-152.

Brown, P. E. \& Parsons, I 1981: The Kap Washington Group volcanics. Rapp. Gronlands geol. Unders. 106, 65-68.

Dawes, P. R. 1971: The North Greenland Fold Belt and environs. Bull. geol. Soc. Denmark 20, 197-239.

Dawes, P. R. 1976: Precambrian to Tertiary of northern Greenland. In: Escher, A. \& Watt, W. S. (eds.) Geology of Greenland, 249-303. Copenhagen, Geol. Surv. Greenland.

Dawes, P. R. \& Peel, J. S. 1981: The northern margin of Greenland from Baffin Bay to the Greenland Sea. In: Nairn, A. E. M., Churkin, M. jr. and Stehli, F. G. (eds.): The Ocean Basins and Margins 5 (The Arctic Ocean), 201-264.

Dawes, P. R. \& Soper, N. J. 1970 Significance of K/Ar age determinations from northern Peary Land. Rapp. Gronlands geol. Unders. 35, 60-62.
Dawes, P. R. \& Soper, N. J. 1973: Pre-Quaternary history of North Greenland. In: Pitcher, M. G. (ed.) Arctic Geology. Mem. Amer. Ass. Petrol. Geol. 19, 117-134.

Hailwood, E. A., Bock, W., Costa, L., Dupeuple, P. A., Muller, C. \& Schnitker, D. 1979: Chronology and biostratigraphy of Northeast Atlantic sediments, DSDP Leg 48. Init. Rep. DSDP 48, 1119-1141.

Håkansson, E., Heinberg, C. \& Stemmerik, L. 1981: The Wandel Sea Basin from Holm Land to Lockwood Ø, Eastern North Greenland. Rapp. Grønlands geol. Unders. 106, 47-63.

Koch, L. 1923: Preliminary report upon the geology of Peary Land, Arctic Greenland. Am. J. Sci., 5th Ser. 5, 189-199.

Larsen, O., Dawes, P. R. \& Soper, N. J. 1978: Rb/Sr age of the Kap Washington Group, Peary Land, North Greenland, and its geotectonic implications. Rapp. Grønlands geol. Unders. 90, 115-119.

McIntyre, G. A., Brooks, C., Compston, W. \& Turek, A. 1966: The statistical assessment of $\mathrm{Rb} / \mathrm{Sr}$ isochrons. J. geophys. Res. 71, 5459-5468.

Soper, N. J., Dawes, P. R. \& Higgins, A. K. (in press): Cretaceous-Tertiary magmatic and tectonic events on North Greenland and the history of adjacent oceanic basins. In: Dawes, P. R. \& Kerr, J. W. (eds.) Nares Strait and the drift of Greenland: a conflict in Plate Tectonics. Meddr. Gronland, Geoscience

Springer, N. 1981: Preliminary $\mathrm{Rb} / \mathrm{Sr}$ age determinations from the North Greenland Fold Belt, Johannes V. Jensen Land, with comments on the metamorphic grade. Rapp. Gronlands geol. Unders. 106, 77-84.

Surlyk, F., Hurst, J. M. \& Bjerreskov, M. 1980: First age-diagnostic fossils from the central part of the North Greenland foldbelt. Nature 286 (5775), 800-803.

Sweeney, J. F., Irving, E. \& Geuer, J. W. 1978: Evolution of the Arctic Basin. In: Sweeney, J. F. (ed.) Arctic Geophysical Review. Publ. Earth Phys. Branch Can., 45(4), 91-100.

Taylor, P. T., Kovacs, L. C., Vogt, P. R. and Johnson, G. L. 1981: Detailed aeromagnetic investigation of the Arctic Basin, 2.J. Geophys. Res. 86, 6323-6333.

Vogt, P. R., Taylor P. T., Kovacs, L. C. \& Johnson, G. L. 1979: Detailed aeromagnetic investigaton of the Arctic Basin. J. geophys. Res. 84, 1071-1089. 